\title{
Registered report: Wnt activity defines colon cancer stem cells and is regulated by the microenvironment
}

\section{James Evans ${ }^{1}$, Anthony Essex ${ }^{1}$, Hong $\mathrm{Xin}^{2}$, Nurith Amitai ${ }^{2}$, Lindsey Brinton ${ }^{3}$, Erin Griner ${ }^{3}$, Reproducibility Project: Cancer Biology*}

${ }^{1}$ PhenoVista Biosciences, San Diego, California; ${ }^{2}$ Explora BioLabs, San Diego, California; ${ }^{3}$ University of Virginia, Charlottesville, Virginia
REPRODUCIBILITY CANCER PCT CANCER BIOLOGY

*For correspondence: tim@cos.io

Group author details

Reproducibility Project: Cancer Biology

See page 16

Competing interests:

See page 16

Funding: See page 17

Received: 03 March 2015 Accepted: 01 August 2015

Published: 19 August 2015

Reviewing editor: Richard J Gilbertson, Cambridge Cancer Center, CRUK Cambridge Institute, United Kingdom

(c) Copyright Evans et al. This article is distributed under the terms of the Creative Commons Attribution License, which permits unrestricted use and redistribution provided that the original author and source are credited.
Abstract The Reproducibility Project: Cancer Biology seeks to address growing concerns about reproducibility in scientific research by replicating selected results from a substantial number of high-profile papers in the field of cancer biology. The papers, which were published between 2010 and 2012, were selected on the basis of citations and Altmetric scores (Errington et al., 2014). This Registered report describes the proposed replication plan of key experiments from 'Wnt activity defines colon cancer stem cells and is regulated by the microenvironment' by Vermeulen and colleagues, published in Nature Cell Biology in 2010 (Vermeulen et al., 2010). The key experiments that will be replicated are those reported in Figures $2 F, 6 \mathrm{D}$, and $7 \mathrm{E}$. In these experiments, Vermeulen and colleagues utilize a reporter for Wnt activity and show that colon cancer cells with high levels of Wnt activity also express cancer stem cell markers (Figure 2F; Vermeulen et al., 2010). Additionally, treatment either with conditioned medium derived from myofibroblasts or with hepatocyte growth factor restored clonogenic potential in low Wnt activity colon cancer cells in vitro (Figure 6D; Vermeulen et al., 2010) and in vivo (Figure 7E; Vermeulen et al., 2010). The Reproducibility Project: Cancer Biology is a collaboration between the Center for Open Science and Science Exchange and the results of the replications will be published in eLife.

DOI: 10.7554/eLife.07301.001

\section{Introduction}

Wnt mediated activation of Frizzled receptors results in translocation of $\beta$-catenin to the nucleus where it binds to TCF/LEF transcription factors to induce expression of Wnt target genes. Wnt signaling proteins mediate a wide variety of biological processes during development, including maintenance of stem cell populations (Malanchi and Huelsken, 2009; Clevers et al., 2014), and aberrant Wnt activation is linked to several diseases, including cancer (Clevers and Nusse, 2012). Vermeulen and colleagues showed that high Wnt activity correlated with markers of colon cancer stem cells and enhanced clonogenic potential of cells (Vermeulen et alo, 2010). They also showed that stromal myofibroblasts secreted factors such as HGF that enhanced Wnt activity and clonogenicity (Vermeulen et al., 2010). Further, treatment of more differentiated cells with myofibroblast conditioned medium (MFCM) enhanced Wnt activity in these cells and enhanced clonogenicity in vitro and in vivo, illustrating that colon cancer cell stemness can be modified by the microenvironment.

To assess Wnt activity in colon cancer cells, Vermeulen and colleagues utilized the TOP-GFP reporter system, a LEF-1/TCF responsive promoter driving expression of the enhanced GFP reporter (Reya et al., 2003). In Figure 2F, colon cancer stem cells were isolated from human colon cancer specimens and transduced with the TOP-GFP reporter. Wnt activity was then assessed using 
fluorescence-activated cell sorting (FACS) in populations derived from a single cell, and flow cytometry was concurrently used to assess the levels of the cancer stem cell markers CD133, CD24/ CD29 or CD44/CD166 in these cells. Vermeulen and colleagues found that cells with high Wnt activity levels correlated with expression of cancer stem cell markers (Vermeulen et al., 2010). Several other reports have used the TOP-GFP system or a similar reporter system to demonstrate that Wht activity was enhanced in a population of cells expressing cancer stem cell markers. Correlation of cancer stem cells markers with high Wnt activity was found in primary and metastatic mouse mammary tumors (Malanchi et al., 2012), spheroid cultures of colon cancer cells (Colak et al., 2014), human and mouse colonic adenomas (Prasetyanti et al., 2013), and primary colon cancer cells (Kemper et al., 2012). All of these studies also found that cells with high Wnt activity maintained clonogenicity, while cells with low Wnt activity had markedly reduced clonogenic potential. In contrast, one report did find that while high Wnt reporter activity did correlate with expression of cancer stem cell markers, the tumorigenic capacity of cells was not dependent upon Wnt activity in four of the five cell lines tested, including three cell lines derived from primary colon cancers (Horst et al., 2012). The experiment presented in Figure $2 \mathrm{~F}$ will be replicated in Protocol 2.

Figure $6 \mathrm{D}$ assessed the potential of MFCM or HGF to enhance the clonogenic potential in vitro of colon cancer cells with low Wnt activity (TOP-GFPlow cells). Clonogenic potential was measured using a limiting dilution assay in which cells were plated at a range of densities and the number of colonies that grow over time was counted. This experiment also examined the ability of the small molecular c-Met inhibitor, PHA-665752, to block MFCM or HGF-mediated clonogenicity. Vermeulen and colleagues showed that treatment of TOP-GFPlow cells with HGF or MFCM increased clonogenicity of these poorly clonogenic cells, and that clonogenicity could be reversed by c-Met inhibition (Vermeulen et al., 2010). Additionally, MET has been reported to be enriched in glioblastoma stem cells (GSCs) and promote their self-renewal (Li et al., 2011; De Bacco et al., 2012; Joo et al., 2012). Met inhibition could also reduce the clonogenic and tumorigenic potential of GSCs, with activation of the Wnt/ $\beta$-catenin signaling pathway shown to be a key mediator of the HGF/Met signaling pathway in these cells (Joo et al., 2012; Kim et al., 2013). This experiment is replicated in Protocol 3. This result was expanded upon in Figure 7E to assess the effect of MFCM on TOP-GFPlow cells in vivo, where Vermeulen and colleagues found that TOP-GFPLow cells coinjected with MFCM, or an admixture of the factors these cells secrete, had enhanced tumorigenicity compared to TOP-GFPLow cells injected alone (Vermeulen et al., 2010). To assess the affect of MFCM on tumorigenicity, limiting dilutions of the different cell populations, in the presence or absence of MFCM, were injected subcutaneously into nude mice and tumor formation was measured over time. Likewise, HGF, along with other cytokines secreted from tumorassociated cells, was demonstrated to increase the tumorigenic activity and metastatic potential of colorectal cancer progenitor cells (Todaro et al., 2014). This experiment is replicated in Protocol 4.

\section{Materials and methods}

\section{Protocol 1: Isolation of colon cancer stem cells and infection with TOP-GFP}

This experiment describes the isolation and culture of colon cancer stem cells. These spheroid cultures and the Co100 cell line used in the original study will be transduced with TOP-GFP and control plasmid. This will produce the single-cell-derived TOP-GFP clones used for further analysis in Protocols 2 and 3.

\section{Sampling}

- This experiment will be performed once to generate two newly derived single spheroidal cultures, which along with the Co100 cell line will provide three colon cancer lines.

- Each of the three lines will be used to generate and isolate 3 different TOP-GFP cancer stem cell (CSC) clones and one control clone. 


\section{Materials and reagents}

\begin{tabular}{|c|c|c|c|c|}
\hline Reagent & Type & Manufacturer & Catalog \# & Comments \\
\hline Modified neurobasal A medium & Cell culture & Life Technologies & $10,888-022$ & Original catalog \# not specified \\
\hline N2 supplement & Cell culture & Life Technologies & $17,502-048$ & Original catalog \# not specified \\
\hline Lipid mixture-1 & Cell culture & Sigma-Aldrich & L0288 & Original catalog \# not specified \\
\hline $\begin{array}{l}\text { Fibroblast growth factor-Basic, } \\
\text { human (FGF) }\end{array}$ & Growth factor & Sigma-Aldrich & F0291 & Original brand not specified \\
\hline Epidermal growth factor, human (EGF) & Growth factor & Sigma-Aldrich & E9644 & Original brand not specified \\
\hline Human colon tissue fragments & Clinical sample & N/A & $\mathrm{N} / \mathrm{A}$ & $\begin{array}{l}\text { Original mainly used microsatellite } \\
\text { stable primary tumors. }\end{array}$ \\
\hline $\begin{array}{l}\text { Phosphate buffered saline (PBS) without } \\
\mathrm{MgCl}_{2} \text { and } \mathrm{CaCl}_{2}\end{array}$ & Buffer & Sigma-Aldrich & D8537 & Original brand not specified* \\
\hline 100x Penicillin/streptomycin & Cell culture & Sigma-Aldrich & P4333 & Original brand not specified* \\
\hline Amphotericin B & Cell culture & Sigma-Aldrich & A2942 & $\begin{array}{l}\text { Replaces GIBCO brand used in original } \\
\text { study* }\end{array}$ \\
\hline $\begin{array}{l}\text { DMEM/F12 medium with L-glutamine } \\
\text { and sodium bicarbonate }\end{array}$ & Cell culture & Sigma-Aldrich & D8062 & $\begin{array}{l}\text { Replaces GIBCO brand used in original } \\
\text { study* }\end{array}$ \\
\hline Collagenase, type $1 \mathrm{~A}-\mathrm{S}$ & Cell culture & Sigma-Aldrich & C9722 & $\begin{array}{l}\text { Replaces Roche brand used in original } \\
\text { study }\end{array}$ \\
\hline $\begin{array}{l}\text { Hyaluronidase from bovine testes, type } \\
1-\mathrm{S}, 400-1000 \text { units/mg }\end{array}$ & Cell culture & Sigma-Aldrich & H3506 & Original brand not specified \\
\hline $40 \mu \mathrm{m}$ cell strainer & Labware & Corning & 431750 & Original brand not specified \\
\hline Lympholyte-M & Chemical & Cedarlane & CL5031 & Original catalog \# not specified \\
\hline Co100 culture & Cell culture & Authors & N/A & From original lab \\
\hline HEK293T cells & Cell line & ATCC & CRL-3216 & $\begin{array}{l}\text { Included during communication with } \\
\text { authors. Original brand not specified }\end{array}$ \\
\hline $\begin{array}{l}\text { Dulbecco's Modified Eagle's Medium } \\
\text { (DMEM)_high glucose }\end{array}$ & Cell culture & Sigma-Aldrich & D6429 & Originally not specified \\
\hline Fetal Bovine Serum (FBS) & Cell culture & Sigma-Aldrich & F0392 & Originally not specified \\
\hline $0.5 \%$ trypsin $/ 0.48 \mathrm{mM}$ EDTA $(5 \mathrm{mg} / \mathrm{ml})$ & Cell culture & Sigma-Aldrich & T4174 & $\begin{array}{l}\text { Included during communication with } \\
\text { authors. Original brand not specified }\end{array}$ \\
\hline $150 \mathrm{~mm}$ tissue culture plates & Labware & Corning & 430599 & $\begin{array}{l}\text { Included during communication with } \\
\text { authors. Original brand not specified }\end{array}$ \\
\hline $100 \mathrm{~mm}$ tissue cultures plates & Labware & Corning & 430167 & Originally not specified \\
\hline TOP-CMV-GFP reporter lentivirus vector & DNA construct & Authors & $\mathrm{N} / \mathrm{A}$ & From original lab \\
\hline psPAX2 packaging plasmid & DNA construct & Authors & $\mathrm{N} / \mathrm{A}$ & From original lab \\
\hline pMD2.G envelope plasmid & DNA construct & Authors & N/A & From original lab \\
\hline TransIT-293 & Transfection reagent & Mirus Bio & MIR 2704 & Originally not specified \\
\hline $50 \mathrm{ml}$ polypropylene conical tubes & Labware & Corning & 430290 & $\begin{array}{l}\text { Included during communication with } \\
\text { authors. Original brand not specified }\end{array}$ \\
\hline OptiMEM-1 reduced serum medium & Cell culture & Life Technologies & 31985062 & $\begin{array}{l}\text { Included during communication with } \\
\text { authors. }\end{array}$ \\
\hline Hexadimethrine bromide (polybrene) & Cell culture & Sigma-Aldrich & 107689 & $\begin{array}{l}\text { Included during communication with } \\
\text { authors. Original brand not specified }\end{array}$ \\
\hline Propidium iodide & Chemical & Sigma-Aldrich & P4170 & Original brand not specified \\
\hline FACS sorter & Equipment & BD Biosciences & FACSaria & \\
\hline $\begin{array}{l}\text { 96-well ultralow-attachment plate, flat } \\
\text { bottom }\end{array}$ & Labware & Corning & 3474 & Original catalog \# not specified \\
\hline 24-well ultralow-attachment plate & Labware & Corning & 3473 & $\begin{array}{l}\text { Included during communication with } \\
\text { authors. }\end{array}$ \\
\hline
\end{tabular}

* Continued on next page 
Continued

\begin{tabular}{lllll} 
Reagent & Type & Manufacturer & Catalog \# & Comments \\
\hline $\begin{array}{l}\text { 6-well ultralow-attachment plate } \\
\begin{array}{l}25 \mathrm{~cm}^{2} \text { ultralow-attachment tissue } \\
\text { culture flask }\end{array}\end{array}$ & Labware & Corning & 3471 & $\begin{array}{l}\text { Included during communication with } \\
\text { authors. }\end{array}$ \\
\hline $\begin{array}{l}75 \mathrm{~cm}^{2} \text { ultralow- attachment tissue } \\
\text { culture flask }\end{array}$ & Labware & Corning & 3815 & Original catalog \# not specified \\
\hline
\end{tabular}

*From (Todaro et al., 2007).

\section{Procedure}

Note:

- This protocol contains information described in Todaro et al., 2007.

- Fresh primary cells and Co100 cell line maintained in CSC medium: modified neurobasal A medium supplemented with $1 \times \mathrm{N} 2$ supplement, lipid mixture-1 $(1 \mathrm{ml} / 500 \mathrm{ml}$ medium), fibroblast growth factor-basic $(20 \mathrm{ng} / \mathrm{ml})$, and epidermal growth factor $(50 \mathrm{ng} / \mathrm{ml})$ at $37^{\circ} \mathrm{C}$ in a humidified atmosphere at $5 \% \mathrm{CO}_{2}$.

- HEK293T cells maintained in DMEM supplemented with $10 \% \mathrm{FBS}$ at $37^{\circ} \mathrm{C}$ with $5 \% \mathrm{CO}_{2}$.

1. Obtain twelve freshly excised human colon adenocarcinoma tissue fragments.

a. If not enough viable spheroidal cultures are generated with the initial twelve fragments, an additional source of human colon adenocarcinoma cells will be obtained.

b. Include histological diagnosis report and patient annotation.

c. Note: with human colon tissue fragment samples, there is a $10-20 \%$ success rate of obtaining spheroidal cultures.

2. Wash 4 times in PBS supplemented with penicillin $(500 \mathrm{U} / \mathrm{ml})$, streptomycin $(500 \mathrm{U} / \mathrm{ml})$, and amphotericin B $(1.25 \mu \mathrm{g} / \mathrm{ml})$.

3. Incubate overnight in DMEM/F12 medium supplemented with penicillin $(500 \mathrm{U} / \mathrm{ml})$, streptomycin $(500 \mathrm{U} / \mathrm{ml})$, and amphotericin B $(1.25 \mu \mathrm{g} / \mathrm{ml})$.

4. Digest with collagenase $(1.5 \mathrm{mg} / \mathrm{ml})$ and hyaluronidase $(20 \mu \mathrm{g} / \mathrm{ml})$ in PBS for $1 \mathrm{hr}$ at $37^{\circ} \mathrm{C}$; shake repeatedly during digestion.

5. Pass the dissociated sample through a $40 \mu \mathrm{m}$ cell strainer and wash with CSC medium.

6. Remove erythrocytes and cell debris by Lympholyte-M centrifugation following manufacturer's instructions.

7. Wash cells 2-3 times with CSC medium and maintain culture. Maintain Co100 cell line following same methodology.

a. Once a viable culture is established, colon cancer cells will cluster into spheroids ( $~ 50-100$ cells/ spheroid).

b. Dissociate spheroids.

i. Pellet spheroids by centrifuging $5 \mathrm{~min}$ at 1000 RPM.

ii. Aspirate medium, being careful not to disrupt cell pellet.

iii. Using a sterile $5 \mathrm{ml}$ serological pipet, gently resuspend cells in $3 \mathrm{ml}$ of $1 \mathrm{mg} / \mathrm{ml}$ trypsin by pipetting up and down $3 \times$.

iv. Place tubes in $37^{\circ} \mathrm{C}$ tissue culture incubator for $2.5 \mathrm{~min}$.

v. Agitate the cells by gently pipetting up and down 3 times using a sterile $5 \mathrm{ml}$ serological pipet.

vi. Return tubes to $37^{\circ} \mathrm{C}$ tissue culture incubator for an additional $2.5 \mathrm{~min}$.

vii. Stop the dissociation by adding $10 \mathrm{ml}$ of DMEM supplemented with $10 \%$ FBS.

viii. Pellet cells by centrifuging 5 min at 1000 RPM.

ix. Aspirate medium, being careful not to disrupt cell pellet.

$x$. Gently resuspend cells in an appropriate volume of CSC medium and perform a viable cell count.

c. Cultures should be passaged when cell concentration exceeds $1 \times 10^{6}$ cells $/ \mathrm{ml}$ of medium. i. Additionaly, maintain cultures, untransduced, as a control for Protocols 2, 3, and 4.

8. Transduce the two newly derived dissociated single spheroidal cultures and the Co100 cell line lentivirally with the TOP-GFP construct following the Trono lab Protocol for 'Production of Lentiviral Vectors in 293T cells' briefly described with the following modifications.

a. Plate $4.7-5.8 \times 10^{6}$ HEK293T cells per $15 \mathrm{~cm}$ plate. 
b. Transfect $15 \mathrm{~cm}$ plate with TOP-GFP lentiviral vector, packaging plasmid, and envelope plasmid with TransIT-293 transfection reagent following Trono lab protocol instructions.

c. Change medium 6-8 hr later and add $15 \mathrm{ml} /$ plate of fresh medium.

d. Harvest $30 \mathrm{ml}$ of medium per plate of transfected HEK293T cells ( $15 \mathrm{ml}$ on day 1 and day 2 after transfection) and filter through a $0.45 \mu \mathrm{m}$ filter.

i. Store day 1 medium at $4^{\circ} \mathrm{C}$ until it can be combined with day 2 harvest.

e. Concentrate by centrifugation $\left(\mathrm{O} / \mathrm{N}\right.$ at $4^{\circ} \mathrm{C}$ and $\left.4000 \mathrm{RPM}\right)$ in a $50 \mathrm{ml}$ polypropylene conical tube.

f. Resuspend virus pellet in $500 \mu$ of Opti-MEM.

g. Transduce dissociated spheroidal cultures with $20 \mu \mathrm{l}$ of concentrated virus $/ 1 \times 10^{6}$ cells in $10 \mathrm{ml}$ of medium supplemented with $8 \mu \mathrm{g} / \mathrm{ml}$ polybrene.

h. Change medium after $24 \mathrm{hr}$ of infection to remove polybrene, dead cells, etc.

9. After 3-4 passages and 2 weeks in culture, or when cells are growing robustly, sort for single, propidium iodide-negative, and GFP-positive cells by FACS.

a. Dissociate spheroids as described in step $7 \mathrm{~b}$.

b. Add $250 \mathrm{ng} / \mathrm{ml}$ propidium iodide solution directly to cells before analysis.

c. Single cells were gated within the GFP positive population.

i. Note: No specific level of GFP was used in the original study.

10. Deposit 1 cell/well in a 96-well ultralow-adhesion plate containing CSC medium.

a. Plate at least three plates with single cells as the incidence of visible spheres is around $1 \%$.

11. After visible spheres arise, transfer to ultralow-adhesion plates and expand three independent TOP-GFP clones from the two newly derived spheroidal cultures and the Co100 cell line.

a. Once spheroid cultures arise from a single cell clone, transfer the spheroid into one well of a 48 well plate and gently break down the spheroid by mechanical dissociation.

b. Slowly scale up to a larger culture surface (i.e., 1 well of a 48 well plate, then 4 wells of a 24 well plate, then 1 well of a 6 well plate, then $25 \mathrm{~cm}^{2}$ flask, etc) by dissociating the culture (as described in step 7b) for the subsequent experiments (Protocols 2, 3, and 4).

12. Maintain clones from single-cell-derived TOP-GFP cells and untransduced parental spheroidal cultures, for further analysis (Protocols 2, 3, and 4).

\section{Deliverables}

- Data to be collected:

Histological diagnosis and patient annotation of human colon tissue fragments.

O All FACS plots in gating scheme (including controls), leading to final population of single, propidium iodide-negative, GFP-positive cells.

- Sample delivered for further analysis:

O Spheroidal cultures (two newly derived and the Co100 cell line) as a control in Protocols 2, 3, and 4.

O Single-cell-derived TOP-GFP clones (two newly derived and the Co100 cell line) for further analysis in Protocols 2, 3, and 4.

Confirmatory analysis plan

N/A.

Known differences from the original study

All known differences are listed in the materials and reagents section above with the originally used item listed in the comments section. All differences have the same capabilities as the original and are not expected to alter the experimental design.

\section{Provisions for quality control}

A report of histological diagnosis and patient annotation will be included. Additionally, cell viability will be monitored during culture conditions. All of the raw data, including the FACS plots, will be uploaded to the project page on the OSF (https://osf.io/pgjhx) and made publically available.

\section{Protocol 2: flow cytometry analysis of CSC marker expression in TOP-GFP clones}

This experiment will assess the association of TOP-GFP levels with CSC marker expression, specifically CD133, CD29, CD24, CD44, and CD166, which is a replication of the experiment reported in Figure $2 \mathrm{~F}$. 


\section{Sampling}

- This experiment will be performed with each of the 3 different TOP-GFP CSC clones from the two newly derived cultures and the Co100 cell line.

- Each TOP-GFP CSC clone will be analyzed for signal intensity for a total power of $\geq 80 \%$. O See 'Power calculations' section for details.

- Staining conditions for each clone:

O CD133.

$\mathrm{O}$ CD24 and CD29.

$\mathrm{O}$ CD24 alone.

O CD29 alone.

O CD44 and CD166.

$\mathrm{O}$ CD44 alone.

O CD166 alone.

O Isotype controls.

O Unstained control.

O Untransduced spheroidal culture (no GFP) control.

Materials and reagents

\begin{tabular}{|c|c|c|c|c|}
\hline Reagent & Type & Manufacturer & Catalog \# & Comments \\
\hline 0.05\% trypsin/0.48 mM EDTA & Cell culture & Sigma-Aldrich & T3924 & Original brand not specified \\
\hline $\begin{array}{l}\text { Phosphate buffered saline (PBS) without } \\
\mathrm{MgCl}_{2} \text { and } \mathrm{CaCl}_{2}\end{array}$ & Buffer & Sigma-Aldrich & D8537 & Originally not specified \\
\hline Bovine serum albumin (BSA) & Chemical & Sigma-Aldrich & A3803 & $\begin{array}{l}\text { Included during communication with } \\
\text { authors. Original brand not specified }\end{array}$ \\
\hline $\begin{array}{l}\text { CD133 (clone AC133) -PE antibody } \\
\text { (mouse IgG1) }\end{array}$ & Antibodies & Miltenyi Biotec & $130-098-826$ & $\begin{array}{l}\text { Use at 1:100 dilution. Conjugate } \\
\text { selected by replicating lab. }\end{array}$ \\
\hline $\begin{array}{l}\text { CD44 (clone G44-26)_-APC antibody } \\
\text { (mouse IgG2b, } \mathrm{k} \text { ) }\end{array}$ & Antibodies & BD Biosciences & 560890 & $\begin{array}{l}\text { Use at 1:100 dilution. Conjugate } \\
\text { selected by replicating lab. }\end{array}$ \\
\hline $\begin{array}{l}\text { CD166 (clone 105902)_-PE antibody } \\
\text { (mouse IgG1) }\end{array}$ & Antibodies & R\&D Systems & FAB6561P & $\begin{array}{l}\text { Original clone listed as } 105901 \text {. Use at } 1 \\
100 \text { dilution. Conjugate selected by } \\
\text { replicating lab. }\end{array}$ \\
\hline $\begin{array}{l}\text { CD24 (clone ML5)_-PE antibody (mouse } \\
\operatorname{lgG} 2 a, \kappa)\end{array}$ & Antibodies & BD Biosciences & 560991 & $\begin{array}{l}\text { Use at } 1: 100 \text { dilution. Conjugate } \\
\text { selected by replicating lab. }\end{array}$ \\
\hline $\begin{array}{l}\text { CD29 (clone MAR4)_APC antibody } \\
\text { (mouse } \operatorname{lgG} 1, \kappa)\end{array}$ & Antibodies & BD Biosciences & 561794 & $\begin{array}{l}\text { Use at 1:100 dilution. Conjugate } \\
\text { selected by replicating lab. }\end{array}$ \\
\hline Anti-lgG1_PE, mouse (clone X-56) & Antibodies & Militenyi Biotec & 130-098-106 & $\begin{array}{l}\text { Use at } 1: 100 \text { dilution. Originally not } \\
\text { specified. }\end{array}$ \\
\hline $\begin{array}{l}\text { Anti-lgG2b к-APC, mouse (clone } \\
\text { 27-35) }\end{array}$ & Antibodies & BD Biosciences & 555745 & $\begin{array}{l}\text { Use at 1:100 dilution. Originally not } \\
\text { specified. }\end{array}$ \\
\hline $\begin{array}{l}\text { Anti-lgG2a к-PE, mouse (clone } \\
\text { G155-178) }\end{array}$ & Antibodies & BD Biosciences & 555574 & $\begin{array}{l}\text { Use at 1:100 dilution. Originally not } \\
\text { specified. }\end{array}$ \\
\hline $\begin{array}{l}\text { Anti-lgG1 } \kappa-A P C \text {, mouse (clone } \\
\text { MOPC-21) }\end{array}$ & Antibodies & BD Biosciences & 555751 & $\begin{array}{l}\text { Use at 1:100 dilution. Originally not } \\
\text { specified. }\end{array}$ \\
\hline Propidium iodide & Chemical & Sigma-Aldrich & P4170 & Original brand not specified \\
\hline FACS sorter & Equipment & BD Biosciences & FACSaria & \\
\hline
\end{tabular}

\section{Procedure}

Note:

- TOP-GFP CSC clones, and untransduced spheroidal culture (no GFP) control, are generated in Protocol 1.

1. After obtaining single cell suspensions in Protocol 1, dissociate TOP-GFP CSC clones and untransduced cultures with trypsin as described in Protocol 1 and re-suspend $1 \times 10^{6}$ cells $/ \mathrm{ml}$ in PBS supplemented with $1 \%$ BSA. 
2. Stain cells with the following antibodies:

a. CD133-PE (use at 1:100 dilution).

b. CD24-PE (use at 1:100 dilution) and CD29-APC (use at 1:100 dilution).

c. CD44-APC (use at 1:100 dilution) and CD166-PE (use at 1:100 dilution).

d. Incubate antibodies with cells for $10 \mathrm{~min}$ in a dark refrigerator at $4^{\circ} \mathrm{C}\left(2-8^{\circ} \mathrm{C}\right.$ is acceptable).

e. Wash cells by adding $20 \times$ the reaction volume of PBS with $1 \%$ BSA and gently inverting tubes $3 \times$ (i.e., cell/antibody volume is $100 \mu \mathrm{l}$, add $2 \mathrm{ml}$ PBS supplemented with $1 \%$ BSA). Centrifuge cells at 1000 RPM for $10 \mathrm{~min}$. Carefully aspirate supernatant completely. Resuspend cells in $100 \mu$ l PBS.

f. Include an unstained control for gating.

g. Include untransduced spheroidal culture (no GFP) for gating.

h. Include isotype control antibody stains.

i. Anti-lgG1-PE.

ii. Anti-lgG2b $\kappa-A P C$.

iii. Anti-lgG2a $\kappa-P E$.

iv. Anti-lgG1 $\kappa-A P C$.

3. Add $250 \mathrm{ng} / \mathrm{ml}$ propidium iodide solution to cells just before analysis.

a. Include an unstained control for gating.

4. Perform flow cytometry analysis for the following populations:

a. Analyze CD133 intensity:

i. Gate for viable cells (propidium iodide-negative cells).

ii. Gate for TOP-GFP expression.

1. Identify top $10 \%$ and bottom $10 \%$ of TOP-GFP expression.

2. Analyze CD133 intensity in at least 10,000 cells in each fraction.

iii. Gate against a negative control (unstained cells).

b. Analyze CD24 and CD29 intensity:

i. Gate for viable cells (propidium iodide-negative cells).

ii. Gate for TOP-GFP expression.

1. Identify top $10 \%$ and bottom $10 \%$ of TOP-GFP expression.

2. Analyze CD29 and CD24 intensity in at least 10,000 cells in each fraction.

iii. Gate against a negative control (unstained cells) and cells stained with each antibody individually.

c. Analyze CD44 and CD166 intensity:

i. Gate for viable cells (propidium iodide-negative cells).

ii. Gate for TOP-GFP expression.

1. Identify top $10 \%$ and bottom $10 \%$ of TOP-GFP expression.

2. Analyze CD44 and CD166 intensity in at least 10,000 cells in each fraction.

iii. Gate against a negative control (unstained cells) and cells stained with each antibody individually.

\section{Deliverables}

- Data to be collected:

O All FACS plots in gating scheme (including controls), leading to final population of propidium iodide-negative, GFP-positive cells for analysis of each CD marker.

O FACS mean fluorescence intensity and confidence intervals for each CD marker.

\section{Confirmatory analysis plan}

This replication attempt will perform the following statistical analysis listed below and compute the effects sizes for each TOP-GFP CSC clone.

- Statistical Analysis:

Note:

1. Since these tests will be performed for each of the three clones from the CSC cultures the alpha error will be adjusted with the Bonferroni correction.

Unpaired, two-tailed t-test with the Bonferroni correction for multiple comparisons:

- CD133 expression from TOP-GFPlow cells compared to TOP-GFPhg cells. 
- CD24 expression from TOP-GFPlow cells compared to TOP-GFPhgh cells.

- CD29 expression from TOP-GFPlow cells compared to TOP-GFPhgh cells.

- CD44 expression from TOP-GFPlow cells compared to TOP-GFPhgh cells.

- CD166 expression from TOP-GFPlow cells compared to TOP-GFPhgh cells.

- Meta-analysis of effect sizes:

O Compare the effect sizes of the TOP-GFP CSC clones from the two newly derived cultures and the Co100 cell line ( 3 different clones each) and use a meta-analytic approach to combine the effects, which will be presented as a forest plot.

Known differences from the original study

All known differences are listed in the materials and reagents section above with the originally used item listed in the comments section. All differences have the same capabilities as the original and are not expected to alter the experimental design.

Provisions for quality control

Negative staining, individual antibody, and isotype controls are included to assess antibody staining relative to background. All of the raw data, including the FACS plots, will be uploaded to the project page on the OSF (https://osf.io/pgjhx) and made publically available.

\section{Protocol 3: clonogenicity assay of TOP-GFP CSC clones}

This experiment will assess the effect of MFCM and recombinant HGF on the clonogenic potential of the TOP-GFP CSC clones. This experiment will also examine the ability of the small molecular c-Met inhibitor, PHA-665752, to block MFCM- or HGF-triggered clonogenicity. This is a replication of the experiment reported in Figure 6D.

\section{Sampling}

- This experiment will be performed with each of the 3 different TOP-GFP CSC clones from the two newly derived cultures and the Co100 cell line and with each cohort assessing 96 wells for a total power of $\geq 80 \%$.

O See 'Power calculations' section for details.

- Each experiment has 8 cohorts:

O Cohort 1: TOP-GFPlow cells.

O Cohort 2: TOP-GFPhigh cells.

O Cohort 3: TOP-GFPlow cells + HGF.

O Cohort 4: TOP-GFPlow cells + MFCM.

O Cohort 5: TOP-GFPlow cells + HGF + PHA-665752.

O Cohort 6: TOP-GFPlow cells + MFCM + PHA-665752.

O Cohort 7: total TOP-GFP cells.

O Cohort 8: total TOP-GFP cells + PHA-665752.

- Each cohort plates (per 96 well plate):

O 1 cell $\times 24$ wells.

O 2 cells $\times 16$ wells.

O 4 cells $\times 8$ wells.

O 8 cells $\times 8$ wells.

O 16 cells $\times 8$ wells.

O 32 cells $\times 8$ wells.

O 64 cells $\times 8$ wells.

O 128 cells $\times 8$ wells.

O 256 cells $\times 8$ wells.

- The titration of cells might need to be adjusted depending on the clonogenic potential of the spheroid clones. An initial pilot experiment will be performed to assess the potential for the three populations (TOP-GFPlow, TOP-GFPhigh, and total TOP-GFP), without treatment, before proceeding with this design. 


\section{Materials and reagents}

\begin{tabular}{|c|c|c|c|c|}
\hline Reagent & Type & Manufacturer & Catalog \# & Comments \\
\hline Modified neurobasal A medium & Cell culture & Life Technologies & $10,888-022$ & Original catalog \# not specified \\
\hline N2 supplement & Cell culture & Life Technologies & $17,502-048$ & Original catalog \# not specified \\
\hline Lipid mixture-1 & Cell culture & Sigma-Aldrich & L0288 & Original catalog \# not specified \\
\hline Fibroblast growth factor-Basic human & Cell culture & Sigma-Aldrich & F0291 & Original brand not specified \\
\hline Epidermal growth factor human & Cell culture & Sigma-Aldrich & E9644 & Original brand not specified \\
\hline $\begin{array}{l}\text { Phosphate buffered saline (PBS) without } \\
\mathrm{MgCl}_{2} \text { and } \mathrm{CaCl}_{2}\end{array}$ & Buffer & Sigma-Aldrich & D8537 & Original brand not specified \\
\hline $0.05 \%$ trypsin/0.48 mM EDTA & Cell culture & Sigma-Aldrich & T3924 & Originally not specified \\
\hline $18 \mathrm{Co}$ cells & Cells & ATCC & CRL-1459 & \\
\hline $\begin{array}{l}\text { Dulbecco's Modified Eagle's Medium } \\
\text { (DMEM)_high glucose }\end{array}$ & Cell culture & Sigma-Aldrich & D5671 & Original brand not specified \\
\hline Fetal Bovine Serum (FBS) & Cell culture & Sigma-Aldrich & F0392 & Original brand not specified \\
\hline L-glutamine & Cell culture & Sigma-Aldrich & G7513 & Original brand not specified \\
\hline Propidium iodide & Chemical & Sigma-Aldrich & P4170 & Original brand not specified \\
\hline FACS sorter & Equipment & BD Biosciences & FACSaria & \\
\hline $\begin{array}{l}\text { 96-well ultralow-attachment plate, flat } \\
\text { bottom }\end{array}$ & Labware & Corning & 3474 & Original catalog \# not specified \\
\hline DMSO & Chemical & Sigma-Aldrich & D8418 & Originally not specified \\
\hline PHA-665752 & Inhibitor & Sigma-Aldrich & PZ0147 & $\begin{array}{l}\text { Replaces Pfizer brand used in original } \\
\text { study }\end{array}$ \\
\hline HGF, human & Growth factor & Sigma-Aldrich & H5791 & $\begin{array}{l}\text { Replaces Relia Tech. Inc. brand used in } \\
\text { original study }\end{array}$ \\
\hline T75 flask & Labware & Corning & $430641 \mathrm{U}$ & Originally not specified \\
\hline Human HGF ELISA kit & Kit & Sigma-Aldrich & RAB0212 & $\begin{array}{l}\text { Included for additional quality control } \\
\text { measure }\end{array}$ \\
\hline $\begin{array}{l}\text { Plate reader capable of measuring } \\
\text { absorbance at } 450 \mathrm{~nm}\end{array}$ & Instrument & & & Used for HGF ELISA \\
\hline Hermes WiScan microscope & Instrument & IDEA Bio-Medical & & Originally not specified \\
\hline
\end{tabular}

\section{Procedure}

Note:

- TOP-GFP CSC clones, and untransduced spheroidal culture (no GFP) control, are generated in Protocol 1.

- CSC cultures maintained in CSC medium: modified neurobasal A medium supplemented with $1 \times$ N2 supplement, lipid mixture-1 $(1 \mathrm{ml} / 500 \mathrm{ml}$ medium), basic fibroblast growth factor $(20 \mathrm{ng} / \mathrm{ml})$, and epidermal growth factor $(50 \mathrm{ng} / \mathrm{ml})$ at $37^{\circ} \mathrm{C}$ in a humidified atmosphere at $5 \% \mathrm{CO}_{2}$.

- $18 \mathrm{Co}$ cells maintained in DMEM supplemented with $10 \% \mathrm{FBS}$ and $1 \%$ glutamine at $37^{\circ} \mathrm{C}$ in a humidified atmosphere at $5 \% \mathrm{CO}_{2}$.

- 18Co cells will be sent for mycoplasma testing and STR profiling.

- An initial pilot experiment, performed once for each clone, will be performed to assess the clonogenic potential of the spheroid cultures. This will be performed with TOP-GFPlow, TOP-GFPhigh, and total TOP-GFP gated populations left untreated (that is they will not be treated after being deposited in step 3 below). Depending on the outcome, the titration of cells might need to be adjusted before proceeding with the entire experiment as described.

1. After obtaining single cell suspensions in Protocol 1, dissociate TOP-GFP CSC clones and untransduced cultures with trypsin as described in Protocol 1 and resuspend $2 \times 10^{6} \mathrm{cells} / \mathrm{ml}$ in $500 \mu \mathrm{l}$ of CSC medium for sorting.

2. Sort for single, propidium iodide-negative, and GFP-positive cells by FACS. a. Add $250 \mathrm{ng} / \mathrm{ml}$ propidium iodide solution directly to cells before analysis. 
i. Include an unstained control for gating.

ii. Include untransduced spheroidal culture (no GFP) for gating.

b. Gate for top $10 \%$ and bottom $10 \%$ for TOP-GFP expression.

c. With an additional sample gate for total TOP-GFP-positive cells.

3. Deposit cells from TOP-GFPlow, TOP-GFPhigh, or total TOP-GFP cell populations into 96-well ultralow-adhesion plates with $100 \mu$ lof one type of medium added to each plate. Plate at 1 cell $\times$ 24 wells, 2 cells $\times 16$ wells, 4 cells $\times 8$ wells, 8 cells $\times 8$ wells, 16 cells $\times 8$ wells, 32 cells $\times 8$ wells, 64 cells $\times 8$ wells, 128 cells $\times 8$ wells, and 256 cells $\times 8$ wells per 96 -well plate. The following medium conditions are used:

a. CSC medium.

b. CSC medium $+500 \mathrm{nM}$ PHA-665752.

c. $\mathrm{CSC}$ medium $+25 \mathrm{ng} / \mathrm{ml} \mathrm{HGF}$.

d. CSC medium + MFCM.

e. CSC medium + $25 \mathrm{ng} / \mathrm{ml} \mathrm{HGF}+500 \mathrm{nM}$ PHA- 665752 .

f. CSC medium + MFCM + 500 nM PHA-665752.

i. Prepare MCFM before treatment as follows:

1. Seed $7.5 \times 10^{5} 18 \mathrm{Co}$ cells in $75-\mathrm{cm}^{2}$ flasks and incubate overnight.

2. The next day wash cells twice with PBS and incubate for $24 \mathrm{hr}$ with $10 \mathrm{ml}$ of CSC medium without EGF and FGF-basic.

3. The next day collect MFCM and clear by centrifugation for 5 min at 1400 RPM.

4. Use at 1:2 dilution in CSC medium.

5. The level of HGF present in MFCM will be determined by an ELISA following manufacturer's instructions.

4. Incubate at $37^{\circ} \mathrm{C}$ for $\sim 10$ days until evaluation of clonogenic potential.

a. Replace with the appropriate culture medium condition every 4 days during incubation.

5. Count the number of cultures with spheres formed by bright field or GFP fluorescence microscopy. a. Exclude any contaminated cultures from analysis.

\section{Deliverables}

- Data to be collected:

O STR profile and result of mycoplasma testing of $18 \mathrm{Co}$ cells.

O Raw data, standard curve, and concentration of HGF in MFCM.

O All FACS plots in gating scheme (including controls), leading to final population of propidium iodide-negative, GFP-positive cells.

O Raw counts of spheroidal cultures and total cultures examined (including if any wells were excluded).

Confirmatory analysis plan

This replication attempt will perform the following statistical analysis listed below and compute the effects sizes for each TOP-GFP CSC clone.

- Statistical Analysis:

Note:

1. Extreme limiting dilution analysis (ELDA) will be used to perform these tests (Hu and Smyth, 2009).

2. Since these tests will be performed for each of the three clones from the CSC cultures the alpha error will be adjusted with the Bonferroni correction.

O Chi-square test for differences between any of the groups.

- Planned pairwise differences between groups with the Bonferroni correction for multiple comparisons:

1. TOP-GFPlow cells compared to TOP-GFPhi cells.

2. TOP-GFPlow cells compared to TOP-GFPlow cells with HGF.

3. TOP-GFPlow cells compared to TOP-GFPlow cells with MFCM.

4. TOP-GFPlow cells with HGF compared to TOP-GFPlow cells with HGF and PHA-665752.

5. TOP-GFPlow cells with MFCM compared to TOP-GFPlow cells with MFCM and PHA-665752.

6. TOP-GFPwhole cells compared to TOP-GFPwhole cells with PHA-665752.

- Meta-analysis of effect sizes:

O Compute the effect sizes of the TOP-GFP CSC clones from the two newly derived cultures and the Co100 cell line (3 different clones each), compare them against the effect size in the original 
paper, and use a meta-analytic approach to combine the original and replication effects, which will be presented as a forest plot.

Known differences from the original study

All known differences are listed in the materials and reagents section above with the originally used item listed in the comments section. All differences have the same capabilities as the original and are not expected to alter the experimental design.

Provisions for quality control

The cell line used in this experiment will undergo STR profiling to confirm its identity and will be sent for mycoplasma testing to ensure there is no contamination. Negative staining and untransduced spheroidal culture are included for gating. An initial experiment, performed once for each clone, will be performed to assess the clonogenic potential of the spheroid cultures to ensure the titration curves are appropriate. The amount of HGF in MFCM will be determined by ELISA to determine 18Co cells are producing HGF. All of the raw data, including the FACS plots, will be uploaded to the project page on the OSF (https://osf.io/pgjhx) and made publically available.

\section{Protocol 4: effect of MFCM on tumorigenicity in TOP-GFPlow CSC clone}

This experiment will assess the effect of MFCM on the tumorigenicity potential of one of the TOP-GFP CSC clones, which is a replication of Figure 7E.

\section{Sampling}

- This experiment will be performed with one of the TOP-GFP CSC clones.

$\bigcirc$ The clone used in this experiment will be from one of the two newly derived cultures with the largest difference in TOP-GFPlow and TOP-GFPhigh as determined from Protocol 3 with untreated cells. If none of the three clones from either culture have differences similar to the reported values in the original study, then the clone with the largest difference from the Co100 cell line will be used.

- Experiment will be performed with 4 mice per injection (a total of 16 mice per cohort) for a total power of $\geq 88 \%$.

See 'Power calculations' section for details.

- Each experiment has 3 cohorts:

O Cohort 1: TOP-GFPlow cells injected into nude mice.

- 10, 100, 1000, and 5000 cells injected.

O Cohort 2: TOP-GFPhigh cells injected into nude mice.

- 10, 100, 1000, and 5000 cells injected.

O Cohort 3: TOP-GFPlow cells + MFCM injected into nude mice.

- $10,100,1000$, and 5000 cells injected.

Materials and reagents

\begin{tabular}{lllll}
\hline Reagent & Type & Manufacturer & Catalog \# & Comments \\
\hline Modified neurobasal A medium & Cell culture & Life technologies & $10,888-022$ & Original catalog \# not specified \\
\hline N2 supplement & Cell culture & Life technologies & $17,502-048$ & Original catalog \# not specified \\
\hline Lipid mixture-1 & Cell culture & Sigma-Aldrich & L0288 & Original catalog \# not specified \\
\hline Fibroblast growth factor_Basic human & Cell culture & Sigma-Aldrich & F0291 & Original brand not specified \\
\hline Epidermal growth factor human & Cell culture & Sigma-Aldrich & E9644 & Original brand not specified \\
\hline $\begin{array}{l}\text { Phosphate buffered saline (PBS) without } \\
\text { MgCl }_{2} \text { and CaCl } 2\end{array}$ & Buffer & Sigma-Aldrich & D8537 & Original brand not specified \\
\hline $\begin{array}{l}\text { 0.05\% trypsin/0.48 mM EDTA } \\
\text { 18Co cells }\end{array}$ & Cell culture & Sigma-Aldrich & T3924 & Originally not specified \\
\hline $\begin{array}{l}\text { Dulbecco's Modified Eagle's Medium } \\
\text { (DMEM)-high glucose }\end{array}$ & Cells & ATCC & CRL-1459 & Original brand not specified \\
\hline
\end{tabular}

Continued on next page 
Continued

\begin{tabular}{|c|c|c|c|c|}
\hline Reagent & Type & Manufacturer & Catalog \# & Comments \\
\hline Fetal Bovine Serum (FBS) & Cell culture & Sigma-Aldrich & F0392 & Original brand not specified \\
\hline L-glutamine & Cell culture & Sigma-Aldrich & G7513 & Original brand not specified \\
\hline T75 flask & Labware & Corning & $430641 \mathrm{U}$ & Originally not specified \\
\hline Human HGF ELISA kit & Kit & Sigma-Aldrich & RAB0212 & $\begin{array}{l}\text { Included for additional quality control } \\
\text { measure }\end{array}$ \\
\hline $\begin{array}{l}\text { Plate reader capable of measuring } \\
\text { absorbance at } 450 \mathrm{~nm}\end{array}$ & Instrument & & & Used for HGF ELISA \\
\hline Propidium iodide & Chemical & Sigma-Aldrich & P4170 & Original brand not specified \\
\hline FACS sorter & Equipment & BD Biosciences & FACSaria & \\
\hline $\begin{array}{l}\text { 96-well ultralow-attachment plate, flat } \\
\text { bottom }\end{array}$ & Labware & Corning & 3474 & Original catalog \# not specified \\
\hline Growth factor reduced Matrigel & Cell culture & Corning & 356230 & Original brand not specified \\
\hline $\begin{array}{l}\text { 8-15 week old female athymic nude mice } \\
\text { (20-30 grams) }\end{array}$ & Animal model & Harlan & $\begin{array}{l}\text { Hsd:Athymic } \\
\text { Nude-Foxn } 1^{\text {nu }}\end{array}$ & \\
\hline $271 / 2$ G needle & Labware & BD Biosciences & 305109 & Original not specified \\
\hline ACE 1 ml Luer Lock syringe & Labware & BD Biosciences & 309628 & Original not specified \\
\hline
\end{tabular}

Procedure

Note:

- TOP-GFP CSC clone is generated in Protocol 1.

- CSC cultures maintained in CSC medium: modified neurobasal A medium supplemented with $1 \times N 2$ supplement, lipid mixture-1 (1 ml/500 ml medium), basic fibroblast growth factor $(20 \mathrm{ng} / \mathrm{ml})$, and epidermal growth factor $(50 \mathrm{ng} / \mathrm{ml})$ at $37^{\circ} \mathrm{C}$ in a humidified atmosphere at $5 \% \mathrm{CO}_{2}$.

- $18 \mathrm{Co}$ cells maintained in DMEM supplemented with $10 \% \mathrm{FCS}$ and $1 \%$ glutamine at $37^{\circ} \mathrm{C}$ in a humidified atmosphere at $5 \% \mathrm{CO}_{2}$.

- 18 Co cells will be sent for mycoplasma testing and STR profiling.

1. After obtaining single cell suspensions in Protocol 1, dissociate TOP-GFP CSC clone and untransduced culture with trypsin as described in Protocol 1 and resuspend $2 \times 10^{6} \mathrm{cells} / \mathrm{ml}$ in $500 \mu$ l of CSC medium for sorting.

2. Sort for single, propidium iodide-negative, and GFP-positive cells by FACS.

a. Add $250 \mathrm{ng} / \mathrm{ml}$ propidium iodide solution directly to cells before analysis.

i. Include an unstained control for gating.

ii. Include untransduced spheroidal culture (no GFP) for gating.

b. Gate for top $10 \%$ and bottom $10 \%$ for TOP-GFP expression.

3. Deposit cells from TOP-GFPlow and TOP-GFPhigh populations into 96-well ultralow-adhesion plates at $10,100,1000$, and 5000 cells per well with $100 \mu$ of the following medium conditions:

a. CSC medium.

b. MFCM.

i. Prepare MCFM before treatment as follows:

1. Seed $7.5 \times 10^{5} 18 \mathrm{Co}$ cells in $75-\mathrm{cm}^{2}$ flasks and incubate overnight.

2. The next day wash cells twice with PBS and incubate for $24 \mathrm{hr}$ with $10 \mathrm{ml}$ of CSC medium without EGF and FGF-basic.

3. The next day collect MFCM and clear by centrifugation for $5 \mathrm{~min}$ at 1400 RPM.

4. Use undiluted.

5. The level of HGF present in MFCM will be determined by an ELISA following manufacturer's instructions.

4. Incubate at $37^{\circ} \mathrm{C}$ for $2 \mathrm{hr}$.

a. After this incubation period, the plates with cells and medium will be placed in a styrofoam container and transported to the facility performing mouse injection/monitoring ( 30 min).

5. Afterwards mix cells and medium $(100 \mu \mathrm{l})$ with Matrigel $(100 \mu \mathrm{l})$ at a $1: 1$ ratio and inject subcutaneously into the right flank of female 8-15 week old Nude mice (20-30 grams) using a sterile $25 \mathrm{G}$ needle and $1 \mathrm{ml}$ syringe.

a. Clean injection site by brief scrubbing with an isopropyl alcohol pad. 
b. 'Tent' the skin of the mouse by gentle pinching with fingers and pulling upwards.

c. During injection, syringe is inserted into subcutaneous tissue and briefly aspirated to ensure the absence of backflow before the contents are fully injected and the needle removed from the injection site.

6. Blindly check mice weekly for a total of 9 weeks. Record if/when tumors become detectable.

a. Monitor by palpitation and caliper measurement of depilated flanks.

i. Caliper measurements will be used to evaluate tumor volumes from their first appearance onwards.

ii. Calculate tumor volume as (length $\times$ width $\left.^{2}\right) / 2$.

d. Confirm tumor presence at endpoint of study by necropsy.

\section{Deliverables}

- Data to be collected:

O STR profile and result of mycoplasma testing of $18 \mathrm{Co}$ cells.

O Raw data, standard curve, and concentration of HGF in MFCM.

O All FACS plots in gating scheme (including controls), leading to final population of propidium iodide-negative, GFP-positive cells.

O Mouse health records (including when tumors become detectable and caliper measurement).

Confirmatory analysis plan

This replication attempt will perform the following statistical analysis listed below.

- Statistical Analysis:

Note:

1. ELDA will be used to perform these tests (Hu and Smyth, 2009).

O Chi-square test for differences between any of the groups.

- Planned pairwise differences between groups with the Bonferroni correction for multiple comparisons:

1. TOP-GFPlow cells compared to TOP-GFPhgh cells.

2. TOP-GFPlow cells compared to TOP-GFPlow cells with MFCM.

- Meta-analysis of effect sizes:

O Compute the effect sizes of each comparison, compare them against the effect size in the original paper and use a meta-analytic approach to combine the original and replication effects, which will be presented as a forest plot.

Known differences from the original study

The experiment requires transporting the cells from a facility that is sorting the cells to another facility ( $30 \mathrm{~min}$ away) to inject and monitor the mice. The replication will not include the TOP-GFPintermediate or TOP-GFPlow with myofibroblasts that were reported for the C100.G7 clone. All known differences are listed in the materials and reagents section above with the originally used item listed in the comments section. All differences have the same capabilities as the original and are not expected to alter the experimental design.

\section{Provisions for quality control}

The cell line used in this experiment will undergo STR profiling to confirm its identity and will be sent for mycoplasma testing to ensure there is no contamination. Additionally, cells will be tested against a rodent pathogen panel to ensure no contamination by pathogens prior to implantation into nude mice. The amount of HGF in MFCM will be determined by ELISA to determine 18Co cells are producing HGF. Negative staining and untransduced spheroidal culture are included for gating. Confirmation of tumor incidence will be confirmed at the end of the study by necropsy. All of the raw data, including the FACS plots, will be uploaded to the project page on the OSF (https://osf.io/pgjhx) and made publically available.

\section{Power calculations}

For additional details on power calculations, please see analysis scripts and associated files on the Open Science Framework:

https://osf.io/rfuj2/. 


\section{Protocol 1}

Not applicable.

\section{Protocol 2}

Original data: unavailable and unable to be estimated.

\section{Test family}

- 2 tailed $t$ test, difference between two independent means: Bonferroni correction: alpha error = 0.003333 (corrected for the three clones from the CSC cultures and the multiple comparisons listed below).

Sensitivity Calculations performed with G*Power software, version 3.1.7 (Faul et al., 2007).

\begin{tabular}{|c|c|c|c|c|c|}
\hline Group 1 & Group 2 & $\begin{array}{l}\text { Detectable } \\
\text { effect size } d^{\star}\end{array}$ & $\begin{array}{l}\text { A priori } \\
\text { power }\end{array}$ & $\begin{array}{l}\text { Group } 1 \\
\text { sample size }\end{array}$ & $\begin{array}{l}\text { Group } 2 \\
\text { sample size }\end{array}$ \\
\hline CD133 from TOP-GFPlow & CD133 from TOP-GFPhigh & 0.053418 & $80.0 \%$ & 10,000 & 10,000 \\
\hline CD24 from TOP-GFPlow & CD24 from TOP-GFPhigh & 0.053418 & $80.0 \%$ & 10,000 & 10,000 \\
\hline CD29 from TOP-GFPlow & CD29 from TOP-GFPhigh & 0.053418 & $80.0 \%$ & 10,000 & 10,000 \\
\hline CD44 from TOP-GFPlow & CD44 from TOP-GFPhigh & 0.053418 & $80.0 \%$ & 10,000 & 10,000 \\
\hline CD166 from TOP-GFPlow & CD166 from TOP-GFPhigh & 0.053418 & $80.0 \%$ & 10,000 & 10,000 \\
\hline
\end{tabular}

*This is the effect size that can be detected with $80 \%$ power and with a sample size of 10,000 cells analyzed per group.

\section{Protocol 3}

Summary of original data (estimated and simulated from Figure 6D) performed with $R$ software, version 3.1.2 (R Development Core Team, 2014).

- The estimated stem cell frequency and 95\% lower confidence interval were used to create simulated data sets with preserved sampling structure using ELDA (Hu and Smyth, 2009).

\begin{tabular}{lllll} 
Dataset being analyzed & Total $\mathbf{N}$ & $\mathbf{9 5 \%} \mathbf{C l}^{\text {lower }}$ & Estimate & $\mathbf{9 5 \%} \mathbf{C l}$ upper \\
\hline TOP-GFPlow & 96 & 99.06 & 63.34 & 40.49 \\
\hline TOP-GFPhigh & 96 & 2.84 & 1.94 & 1.32 \\
\hline TOP-GFPlow + HGF & 96 & 8.77 & 5.80 & 3.84 \\
\hline TOP-GFPlow + MFCM & 96 & 8.97 & 5.93 & 3.92 \\
\hline TOP-GFPlow + HGF + PHA-665752 & 96 & 155.75 & 98.15 & 61.85 \\
\hline TOP-GFPlow + MFCM + PHA-665752 & 96 & 478 & 266.21 & 148.26 \\
\hline TOP-GFPwhole & 96 & 9.14 & 6.04 & 3.99 \\
\hline TOP-GFPwhole + PHA-665752 & 96 & 8.26 & 5.47 & 3.62
\end{tabular}

\section{Test family}

- Chi-square test, differences between any of the groups: Bonferroni correction: alpha error = 0.01667 (corrected for the three clones from the CSC cultures).

Power calculations performed with R software, version 3.1.2 (R Development Core Team, 2014).

\begin{tabular}{|c|c|c|c|c|}
\hline Groups & $\chi^{2}$ test statistic & Cohen's w & A priori power & Total sample size \\
\hline $\begin{array}{l}\text { TOP-GFPlow, TOP-GFPhigh, TOP-GFPlow + HGF, TOP-GFPlow + } \\
\text { MFCM, TOP-GFPlow + HGF + PHA-665752 TOP-GFPlow + MFCM } \\
\text { + PHA-665752, TOP-GFPwhole, TOP-GFPwhole + PHA-665752 }\end{array}$ & 731 & 0.975614 & $99.9 \%$ & 768 (8 groups) \\
\hline
\end{tabular}




\section{Test family}

- Chi-square test, pairwise differences between groups: Bonferroni correction: alpha error = 0.002778 .

Power calculations performed with R software, version 3.1.2 (R Development Core Team, 2014).

\begin{tabular}{|c|c|c|c|c|c|c|}
\hline Group 1 & Group 2 & $\begin{array}{l}\chi^{2} \text { test } \\
\text { statistic }\end{array}$ & Cohen's w & $\begin{array}{l}\text { A priori } \\
\text { power }\end{array}$ & $\begin{array}{l}\text { Group } 1 \\
\text { sample size }\end{array}$ & $\begin{array}{l}\text { Group } 2 \\
\text { sample size }\end{array}$ \\
\hline TOP-GFPlow & TOP-GFPhigh & 173 & 0.949232 & $99.9 \%$ & 96 & 96 \\
\hline TOP-GFPlow & TOP-GFPlow + HGF & 114 & 0.770552 & $99.9 \%$ & 96 & 96 \\
\hline TOP-GFPlow & TOP-GFPlow + MFCM & 102 & 0.728869 & $99.9 \%$ & 96 & 96 \\
\hline TOP-GFPlow + HGF & TOP-GFPlow + HGF + PHA-665752 & 153 & 0.892679 & $99.9 \%$ & 96 & 96 \\
\hline TOP-GFPlow + MFCM & TOP-GFPlow + MFCM + PHA-665752 & 186 & 0.984251 & $99.9 \%$ & 96 & 96 \\
\hline TOP-GFPwhole & TOP-GFPwhole + PHA-665752 & $0.212^{\star}$ & $0.251143^{\star}$ & $80.0 \% *$ & 96 & 96 \\
\hline
\end{tabular}

*A sensitivity calculation was performed since the original data showed a non-significant effect. This is the $\chi^{2}$ test statistic and effect size that can be detected with $80 \%$ power

\section{Protocol 4}

Summary of original data (obtained from Figure 7E) performed with $R$ software, version 3.1.2 (R Development Core Team, 2014).

- The estimated stem cell frequency and 95\% lower confidence interval were used to create simulated data sets with preserved sampling structure using ELDA (Hu and Smyth, 2009).

- Both clones reported in Figure 7E were used to determine sample size to ensure an adequate number of mice are used to detect either effect size.

\begin{tabular}{lllll} 
Dataset being analyzed (C100.B5) & total $\mathbf{N}$ & $\mathbf{9 5 \%} \mathbf{C l}$ lower & Estimate & $\mathbf{9 5 \%} \mathbf{C l}$ upper \\
\hline TOP-GFPlow & 24 & $18,841.8$ & 6939.2 & 2555.8 \\
\hline TOP-GFPhigh & 18 & 92.2 & 37.1 & 15.1 \\
\hline TOP-GFPlow + MFCM & 24 & 789.3 & 310.9 & 122.6 \\
\hline
\end{tabular}

\section{Test family}

- Chi-square test, differences between any of the groups: alpha error $=0.05$.

Power calculations performed with R software, version 3.1.2 (R Development Core Team, 2014).

\begin{tabular}{lllll} 
Groups & $\chi^{2}$ test statistic & Cohen's w & A priori power & Total sample size \\
\hline $\begin{array}{l}\text { TOP-GFPlow }, \text { TOP-GFPhigh, } \\
\text { TOP-GFPlow' }+ \text { MFCM }\end{array}$ & 75.7 & 1.070967 & $99.9 \%$ & 48 (3 groups) \\
\hline
\end{tabular}

\section{Test family}

- Chi-square test, pairwise differences between groups: Bonferroni correction: alpha error $=0.025$.

Power calculations performed with R software, version 3.1.2 (R Development Core Team, 2014).

\begin{tabular}{lllllll}
\hline Group 1 & Group 2 & $\chi^{2}$ test statistic & Cohen's w & A priori power & Group 1 sample size & Group 2 sample size \\
\hline TOP-GFPlow & TOP-GFPhigh & 65.2 & 1.245946 & $99.9 \%$ & 16 & 16 \\
\hline TOP-GFPlow & TOP-GFPlow + MFCM & 26 & 0.735980 & $97.3 \%$ & 16 & 16
\end{tabular}


Summary of original data (obtained from Figure 7E) performed with $R$ software, version 3.1.2 (R Development Core Team, 2014).

\begin{tabular}{lllll} 
Dataset being analyzed (C100.G7) & total $\mathbf{N}$ & $\mathbf{9 5 \%} \mathbf{C l}$ lower & Estimate & $\mathbf{9 5 \%} \mathbf{C l}^{\text {upper }}$ \\
\hline TOP-GFPlow & 24 & Infinity & Infinity & 12,238 \\
\hline TOP-GFPhigh & 18 & 2499 & 961 & 370 \\
\hline TOP-GFPlow + MFCM & 24 & 5237 & 2352 & 1057 \\
\hline
\end{tabular}

Test family

- Chi-square test, differences between any of the groups: alpha error $=0.05$.

Power calculations performed with R software, version 3.1.2 (R Development Core Team, 2014).

\begin{tabular}{lllll} 
Groups & $\chi^{2}$ test statistic & Cohen's w & A priori power & Total sample size \\
\hline TOP-GFPlow ${ }^{\prime}$ TOP-GFPhigh, & 26.5 & 0.633652 & $98.19 \%$ & 48 (3 groups) \\
TOP-GFPlow + MFCM & & &
\end{tabular}

Test family

- Chi-square test, pairwise differences between groups: Bonferroni correction: alpha error $=0.025$.

Power calculations performed with R software, version 3.1.2 (R Development Core Team, 2014).

\begin{tabular}{|c|c|c|c|c|c|c|}
\hline Group 1 & Group 2 & $\chi^{2}$ test statistic & Cohen's w & A priori power & $\begin{array}{l}\text { Group } 1 \\
\text { sample size }\end{array}$ & $\begin{array}{l}\text { Group } 2 \\
\text { sample size }\end{array}$ \\
\hline TOP-GFPlow & TOP-GFPhigh & 21.3 & 0.712140 & $96.3 \%$ & 16 & 16 \\
\hline TOP-GFPlow & TOP-GFPlow + MFCM & 17.5 & 0.603807 & $88.0 \%$ & 16 & 16 \\
\hline
\end{tabular}

\section{Acknowledgements}

The Reproducibility Project: Cancer Biology core team would like to thank the original authors, in particular Jan Paul Medema and Giorgio Stassi, for generously sharing critical information and reagents to ensure the fidelity and quality of this replication attempt. We thank Courtney Soderberg at the Center for Open Science for assistance with statistical analyses. We would also like to thank the following companies for generously donating reagents to the Reproducibility Project: Cancer Biology; American Type Culture Collection (ATCC), Applied Biological Materials, BioLegend, Charles River Laboratories, Corning Incorporated, DDC Medical, EMD Millipore, Harlan Laboratories, LI-COR Biosciences, Mirus Bio, Novus Biologicals, Sigma-Aldrich, and System Biosciences (SBI).

\section{Additional information}

Group author details

\section{Reproducibility Project: Cancer Biology}

Elizabeth Iorns: Science Exchange, Palo Alto, California; William Gunn: Mendeley, London, United Kingdom; Fraser Tan: Science Exchange, Palo Alto, California; Joelle Lomax: Science Exchange, Palo Alto, California; Timothy Errington: Center for Open Science, Charlottesville, Virginia

Competing interests

JE: PhenoVista Biosciences is a Science Exchange associated laboratory. AE: PhenoVista Biosciences is a Science Exchange associated laboratory. HX: Explora BioLabs is a Science Exchange associated laboratory. NA: Explora BioLabs is a Science Exchange associated laboratory. RP:CB: El, FT, JL: Employed by and hold shares in Science Exchange Inc. The other authors declare that no competing interests exist. 
Funding

Funder

Author

Laura and John Arnold

Foundation

Reproducibility Project: Cancer

Biology

The Reproducibility Project: Cancer Biology is funded by the Laura and John Arnold Foundation, provided to the Center for Open Science in collaboration with Science Exchange. The funder had no role in study design or the decision to submit the work for publication.

Author contributions

JE, AE, HX, NA, LB, EG, Drafting or revising the article; RP:CB, Conception and design, Drafting or revising the article

\section{References}

Clevers H, Loh KM, Nusse R. 2014. Stem cell signaling. An integral program for tissue renewal and regeneration: Wnt signaling and stem cell control. Science 346:1248012. doi: 10.1126/science.1248012.

Clevers H, Nusse R. 2012. Wnt/beta-catenin signaling and disease. Cell 149:1192-1205. doi: 10.1016/j.cell.2012. 05.012.

Colak S, Zimberlin CD, Fessler E, Hogdal L, Prasetyanti PR, Grandela CM, Letai A, Medema JP. 2014. Decreased mitochondrial priming determines chemoresistance of colon cancer stem cells. Cell Death and Differentiation 21: 1170-1177. doi: 10.1038/cdd.2014.37.

De Bacco F, Casanova E, Medico E, Pellegatta S, Orzan F, Albano R, Luraghi P, Reato G, D'Ambrosio A, Porrati P, Patane M, Maderna E, Pollo B, Comoglio PM, Finocchiaro G, Boccaccio C. 2012. The MET oncogene is a functional marker of a glioblastoma stem cell subtype. Cancer Research 72:4537-4550. doi: 10.1158/00085472.CAN-11-3490.

Errington TM, lorns E, Gunn W, Tan FE, Lomax J, Nosek BA. 2014. An open investigation of the reproducibility of cancer biology research. eLife 3:e04333. doi: 10.7554/eLife.04333.

Faul F, Erdfelder E, Lang AG, Buchner A. 2007. G*Power 3: a flexible statistical power analysis program for the social, behavioral, and biomedical sciences. Behavior Research Methods 39:175-191. doi: 10.3758/BF03193146.

Horst D, Chen J, Morikawa T, Ogino S, Kirchner T, Shivdasani RA. 2012. Differential WNT activity in colorectal cancer confers limited tumorigenic potential and is regulated by MAPK signaling. Cancer Research 72 : 1547-1556. doi: 10.1158/0008-5472.CAN-11-3222.

Hu Y, Smyth GK. 2009. ELDA: extreme limiting dilution analysis for comparing depleted and enriched populations in stem cell and other assays. Journal of Immunological Methods 347:70-78. doi: 10.1016/j.jim. 2009.06.008.

Joo KM, Jin J, Kim E, Ho Kim K, Kim Y, Gu Kang B, Kang YJ, Lathia JD, Cheong KH, Song PH, Kim H, Seol HJ, Kong DS, Lee JI, Rich JN, Lee J, Nam DH. 2012. MET signaling regulates glioblastoma stem cells. Cancer Research 72: 3828-3838. doi: 10.1158/0008-5472.CAN-11-3760.

Kemper K, Prasetyanti PR, De Lau W, Rodermond H, Clevers H, Medema JP. 2012. Monoclonal antibodies against Lgr5 identify human colorectal cancer stem cells. Stem Cells 30:2378-2386. doi: 10.1002/stem.1233.

Kim KH, Seol HJ, Kim EH, Rheey J, Jin HJ, Lee Y, Joo KM, Lee J, Nam DH. 2013. Wnt/beta-catenin signaling is a key downstream mediator of MET signaling in glioblastoma stem cells. Neuro-Oncology 15:161-171. doi: 10. 1093/neuonc/nos299.

Li Y, Li A, Glas M, Lal B, Ying M, Sang Y, Xia S, Trageser D, Guerrero-Cazares H, Eberhart CG, Quinones-Hinojosa A, Scheffler B, Laterra J. 2011. c-Met signaling induces a reprogramming network and supports the glioblastoma stem-like phenotype. Proceedings of the National Academy of Sciences of USA 108:9951-9956. doi: 10.1073/ pnas.1016912108.

Malanchi I, Huelsken J. 2009. Cancer stem cells: never Wnt away from the niche. Current Opinion in Oncology 21: 41-46. doi: 10.1097/CCO.0b013e32831d1faf.

Malanchi I, Santamaria-Martinez A, Susanto E, Peng H, Lehr HA, Delaloye JF, Huelsken J. 2012. Interactions between cancer stem cells and their niche govern metastatic colonization. Nature 481:85-89. doi: 10.1038/ nature10694.

Prasetyanti PR, Zimberlin CD, Bots M, Vermeulen L, Melo Fde S, Medema JP. 2013. Regulation of stem cell selfrenewal and differentiation by Wnt and Notch are conserved throughout the adenoma-carcinoma sequence in the colon. Molecular Cancer 12:126. doi: 10.1186/1476-4598-12-126.

R Development Core Team. 2014. R: A language and environment for statistical computing. $R$ foundation for statistical computing. http://www.R-project.org/.

Reya T, Duncan AW, Ailles L, Domen J, Scherer DC, Willert K, Hintz L, Nusse R, Weissman IL. 2003. A role for Wnt signalling in self-renewal of haematopoietic stem cells. Nature 423:409-414. doi: 10.1038/ nature01593.

Todaro M, Alea MP, Di Stefano AB, Cammareri P, Vermeulen L, lovino F, Tripodo C, Russo A, Gulotta G, Medema JP, Stassi G. 2007. Colon cancer stem cells dictate tumor growth and resist cell death by production of interleukin-4. Cell Stem Cell 1:389-402. doi: 10.1016/j.stem.2007.08.001. 
Todaro M, Gaggianesi M, Catalano V, Benfante A, lovino F, Biffoni M, Apuzzo T, Sperduti I, Volpe S, Cocorullo G, Gulotta G, Dieli F, De Maria R, Stassi G. 2014. CD44v6 is a marker of constitutive and reprogrammed cancer stem cells driving colon cancer metastasis. Cell Stem Cell 14:342-356. doi: 10.1016/j.stem.2014. 01.009.

Vermeulen L, De Sousa EM, van der Heijden M, Cameron K, de Jong JH, Borovski T, Tuynman JB, Todaro M, Merz C, Rodermond H, Sprick MR, Kemper K, Richel DJ, Stassi G, Medema JP. 2010. Wnt activity defines colon cancer stem cells and is regulated by the microenvironment. Nature Cell Biology 12:468-476. doi: 10.1038/ ncb2048. 